\title{
Molecular characterization of a fungal gene paralogue of the penicillin penDE gene of Penicillium chrysogenum Carlos García-Estrada1 ${ }^{1}$ Inmaculada Vaca1 ${ }^{1}$, Ricardo V Ullán1, Marco A van den Berg2 ${ }^{2}$, Roel AL Bovenberg ${ }^{2}$ and Juan Francisco Martín*1,3
}

Address: ${ }^{1}$ Instituto de Biotecnología (INBIOTEC), Parque Científico de León, Av. Real, 1, 24006, León, Spain, ${ }^{2}$ DSM Anti-Infectives, DSM Gist (624-0270), PO Box 425, 2600 AK, Delft, the Netherlands and '3Área de Microbiología, Departamento de Biología Molecular, Facultad de CC Biológicas y Ambientales, Universidad de León, Campus de Vegazana s/n. 24071, León, Spain

Email: Carlos García-Estrada - c.gestrada@unileon.es; Inmaculada Vaca - ivacc@unileon.es; Ricardo V Ullán - rvicu@unileon.es; Marco A van den Berg - Marco.Berg-van-den@DSM.COM; Roel AL Bovenberg - Roel.Bovenberg@DSM.COM; Juan Francisco Martín* - jf.martin@unileon.es

* Corresponding author

Published: 26 May 2009

BMC Microbiology 2009, 9:104 doi:10.1186/147|-2180-9-104
Received: 10 November 2008

Accepted: 26 May 2009

This article is available from: http://www.biomedcentral.com//47/-2/80/9//04

(c) 2009 García-Estrada et al; licensee BioMed Central Ltd.

This is an Open Access article distributed under the terms of the Creative Commons Attribution License (http://creativecommons.org/licenses/by/2.0), which permits unrestricted use, distribution, and reproduction in any medium, provided the original work is properly cited.

\begin{abstract}
Background: Penicillium chrysogenum converts isopenicillin N (IPN) into hydrophobic penicillins by means of the peroxisomal IPN acyltransferase (IAT), which is encoded by the penDE gene. In silico analysis of the $P$. chrysogenum genome revealed the presence of a gene, Pc|3g09|40, initially described as paralogue of the IAT-encoding penDE gene. We have termed this gene ial because it encodes a protein with high similarity to IAT (IAL for IAT-Like). We have conducted an investigation to characterize the ial gene and to determine the role of the IAL protein in the penicillin biosynthetic pathway.

Results: The IAL contains motifs characteristic of the IAT such as the processing site, but lacks the peroxisomal targeting sequence ARL. Null ial mutants and overexpressing strains indicated that IAL lacks acyltransferase (penicillin biosynthetic) and amidohydrolase (6-APA forming) activities in vivo. When the canonical ARL motif (leading to peroxisomal targeting) was added to the $C$-terminus of the IAL protein (IALARL) by site-directed mutagenesis, no penicillin biosynthetic activity was detected. Since the IAT is only active after an accurate self-processing of the preprotein into $\alpha$ and $\beta$ subunits, self-processing of the IAL was tested in Escherichia coli. Overexpression experiments and SDS-PAGE analysis revealed that IAL is also self-processed in two subunits, but despite the correct processing, the enzyme remained inactive in vitro.

Conclusion: No activity related to the penicillin biosynthesis was detected for the IAL. Sequence comparison among the $P$. chrysogenum IAL, the A. nidulans IAL homologue and the IAT, revealed that the lack of enzyme activity seems to be due to an alteration of the essential Ser309 in the thioesterase active site. Homologues of the ial gene have been found in many other ascomycetes, including non-penicillin producers. Our data suggest that like in $A$. nidulans, the ial and penDE genes might have been formed from a single ancestral gene that became duplicated during evolution, although a separate evolutive origin for the ial and penDE genes, is also discussed.
\end{abstract}




\section{Background}

The $\beta$-lactams are one of the most important classes of antibiotics. They are produced by different microorganisms, including filamentous fungi such as Penicillium chrysogenum and Aspergillus nidulans. These ascomycetes synthesize hydrophobic penicillins using three amino acids as precursors; L- $\alpha$-aminoadipic acid, L-cysteine and L-valine to form the tripeptide $\delta$ (L- $\alpha$-aminoadipyl)-Lcysteinyl-D-valine (ACV) by the multienzyme ACV synthetase (ACVS), which is encoded by the $p c b A B$ gene. This tripeptide is converted into isopenicillin N (IPN), a reaction catalyzed by the IPN synthase (IPNS) encoded by the $p c b \mathrm{C}$ gene [1]. In the last step of the penicillin pathway, the L- $\alpha$-aminoadipyl side chain of IPN is substituted by aromatic acyl side chains to form hydrophobic penicillins. This reaction is catalysed by the isopenicillin $\mathrm{N}$ acyltransferase (IAT), encoded by the penDE gene $[2,3]$. Previous activation of the aromatic acid by a specific arylCoA ligase is required $[4,5]$.

In $P$. chrysogenum, the $p c b A B, p c b C$ and $p e n D E$ genes are clustered with other ORFs forming an amplifiable DNA unit [6-8]. These other ORFs play only a minor role in the penicillin biosynthesis, since complementation of the npe10 strain $(\Delta p e n)$, which lacks the whole amplified region including the penicillin gene cluster $[9,10]$, with only the $p c b A B, p c b C$ and penDE genes restored full $\beta$ lactam synthesis $[8,11]$.

The evolutionary origin of the penicillin gene cluster is intriguing [12]. The first two genes $p c b A B$ and $p c b C$ do not contain introns despite the large size of $p c b A B(11 \mathrm{~kb})$; they appear to have been transferred from $\beta$-lactam producing bacteria [13-15], unlike the IAT-encoding penDE gene, which contains three introns and seems to have been recruited from the fungal genomes.

The last enzyme of the penicillin biosynthetic pathway (IAT) is synthesized as a $40-\mathrm{kDa}$ precursor (proacyltransferase, proIAT), which undergoes an autocatalytic selfprocessing between residues Gly102-Cys103 in P. chrysogenum. The processed protein constitutes an active heterodimer with subunits $\alpha(11 \mathrm{kDa}$, corresponding to the $\mathrm{N}$-terminal fragment) and $\beta(29 \mathrm{kDa}$, corresponding to the C-terminal region) [16-20]. The IAT has up to five enzyme activities related to penicillin biosynthesis [21]. The substitution of the side chain either occurs directly through the IPN acyltransferase activity, or as a two-step process through the IPN amidohydrolase activity, thus forming 6-aminopenicillanic acid (6-APA) as an intermediate [22].

The $P$. chrysogenum IAT belongs to the N-terminal nucleophile (NTN) family of proteins and it is capable of selfactivation (C. García-Estrada and J.F. Martín, unpublished results), as occurs with other NTN amidohydrolases [23]. This enzyme is located inside microbodies (peroxisomes) $[24,25]$ and its transport inside the peroxisomal matrix is not dependent on the processing state of the protein; the unprocessed proIAT variant IATC103S is correctly targeted to peroxisomes, although it is not active [26].

In silico analysis of the $P$. chrysogenum genome revealed the presence of a gene, Pc13g09140, initially described as paralogue of the IAT-encoding penDE gene [27]. It was, therefore, of great interest to characterize the ial gene at the molecular level and its relationship with the penDE gene regarding penicillin biosynthesis.

\section{Results \\ Characterization of the ial gene in $\mathbf{P}$. chrysogenum, which encodes a protein (IAL) with high similarity to IAT}

The genome of $P$. chrysogenum Wis54-1255 contains a gene (Pc13g09140) that was initially described as paralogue of the penicillin biosynthetic penDE gene [27]. We have confirmed by sequence analysis that this gene is $100 \%$ identical to that in the wild-type strain NRRL 1951, indicating that further industrial strain improvement steps have not modified the sequence of this gene. We have termed this gene ial because it encodes a protein (IAL for IAT-Like) that shares a 54\% similarity (E-value 6e-43, $34 \%$ identity) and a 52\% similarity (E-value 5e-42, 35\% identity) with the IATs of $P$. chrysogenum and A. nidulans, respectively. In addition, the IAL showed $81 \%$ similarity with an unnamed protein product from A. oryzae (GenBank: BAE55742), 80\% similarity with a putative IAT of $A$. clavatus (GenBank: XP 001271254), 79\% similarity with the hypothetical protein An02g08570 from A. niger (GenBank: XP_001399990), 78\% similarity with a predicted protein from A. terreus (GenBank: XP 001213312), 76\% similarity with a putative IAT from Neosartorya fischeri (GenBank: XP 001263202), 76\% similarity with a putative IAT from A. fumigatus (GenBank: XP 754359) and $60 \%$ similarity with the hypothetical protein AN6775.2 of A. nidulans (GenBank: XP 664379), among others (Fig. $1)$. The IAL protein is present in several of the sequenced genomes of ascomycetes and deuteromycetes.

It is noteworthy that the P. chrysogenum IAL shows some important amino acids and domains that are present in the wild-type IAT, such as the 104 DGCTS 108 motif (equivalent to the 101 DGCTT 105 motif of the IAT containing the G102-C103 processing site) and the S231, which is equivalent to the IAT S227 residue required for IAT cleavage and activity [20]. However, the peroxisomal targeting sequence (PTS1) is absent from the $\mathrm{C}^{\prime}$-end of the $P$. chrysogenum IAL and related proteins from other filamentous fungi, unlike what is observed in the P. chrysogenum and A. nidulas IATs, which bear the PTS1 ARL and ANI motifs, respectively (Fig. 1). 

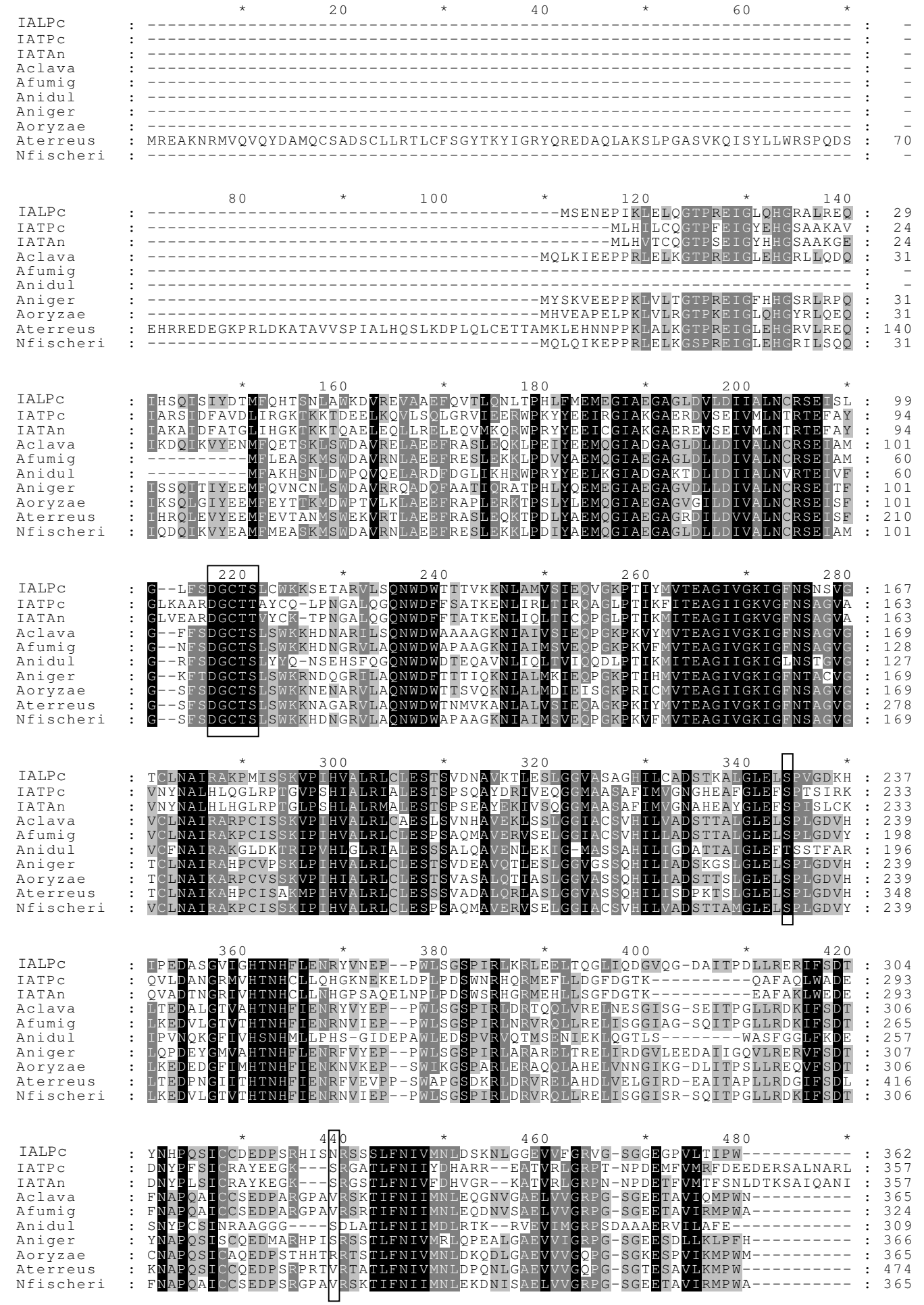

Figure I

Alignment of the $P$. chryosogenum IAL (IALPc) to the IATs of $P$. chrysogenum (IATPc) and A. nidulans (IATAn) and to different homologues of the IAL present in filamentous fungi such as $A$. clavatus (Aclava), $A$. fumigatus (Afumig), A. nidulans (Anidul), A. niger (Aniger), A. oryzae (Aoryzae), A. terreus (Aterreus) and N. fischeri (Nfischeri). Those motifs or residues important for IAT enzyme processing or activity are boxed. 
Penicillin biosynthesis is not affected in the ial null mutant In order to test whether the IAL protein participates in the biosynthesis of penicillin in P. chrysogenum, we studied the function of the gene in a penicillin high-producing strain, DS17690 [28]. In order to generate null mutants in the ial gene without disturbing the genomic context, the amdS marker was inserted between the ial promoter and its ORF, in the opposite orientation (see Fig. 2). To increase the rate of homologous targeting, a derivative of P. chrysogenum DS17690, in which the Non-Homologous End-Joining pathway is disturbed, was used as a host strain. As described for other fungi $[29,30]$ deletion of the $P$. chrysogenum KU70 homologue increases the frequency of homologous recombination significantly (Marco A. van den Berg, unpublished results). Acetamide-consuming transformants were obtained, purified on fresh media and verified for the correct insertion by PCR. Shake flask experiments demonstrated that the ial null mutant had no effect on penicillin production in CP medium supplemented with either precursor, adipate or phenylactetate (103+/- $1 \%$ as compared to both DS17690 and DS54465 strains; $100 \%)$.

Expression of the ial gene in $\mathbf{P}$. chrysogenum and in vivo role of the IAL in the benzylpenicillin biosynthetic pathway To confirm these results, we carried out different experiments with the engineered strain $P$. chrysogenum npe10$A B \cdot C$. This strain is a transformed derivative of the npe 10 PyrG- strain ( $\Delta$ pen) that contains the $p c b A B$ and $p c b C$ genes, but lacks the wild-type penDE gene [11]. Because of these features, this strain is optimal to assess the putative role of the IAL protein in the benzylpenicillin biosynthetic pathway. The integrity of the ial gene in the npe10-AB $C$ strain was initially tested by PCR (data not shown) and
Southern blotting (Fig. 3A). After digestion of the genomic DNA with HindIII, one 11-kbp band was observed in the npe $10-A B \cdot C$, size that is coincident with that provided by the Wis54-1255 strain digested with the same restriction enzymes (Fig. 3A). However, after sequencing the ial gene from the npe10-AB $C$ strain, we found a point mutation at nucleotide 980 , where $C$ was changed into $\mathrm{T}$ (see Discussion). IPN production by the npe $10-A B \cdot C$ strain was confirmed by HPLC (Fig. 3B). Formation of benzylpenicillin (IPN acyltransferase activity) and 6-APA (IPN amidohydrolase activity) that might be catalyzed by the IAL, were assessed by growing the npe10$A B \cdot C$ strain in CP medium. Samples were taken at $48 \mathrm{~h}$ and $72 \mathrm{~h}$, but neither 6-APA (Fig. 3C) nor benzylpenicillin (Fig. 3D) were detected by HPLC. This indicates that the npe $10-A B \cdot C$ strain, which contains the ial gene, does not produce these compounds formed in the last step of the penicillin biosynthetic pathway. To test whether the lack of activity is due to a low or null expression rate of the ial gene, northern blot experiments were done with samples taken from the npe10-AB $C$ and the Wis54-1255 strains grown in CP medium. As shown in Fig. $3 \mathrm{E}$ no transcript bands were detected at 24 or $48 \mathrm{~h}$, indicating that this gene is very low or not expressed in P. chrysogenum, in agreement with the absence of detectable ial mRNA in $P$. chrysogenum NRRL 1951, npe10, Wisconsin54-1255 and DS17690 strains (Marco A. van den Berg, unpublished results).

\section{Overexpression of the ial gene in the $\mathbf{P}$. chrysogenum npe I 0-AB C C strain}

To assure high levels of the ial gene transcript, this gene (without the point mutation at nucleotide 980) was amplified from P. chrysogenum Wis54-1255 and overex-

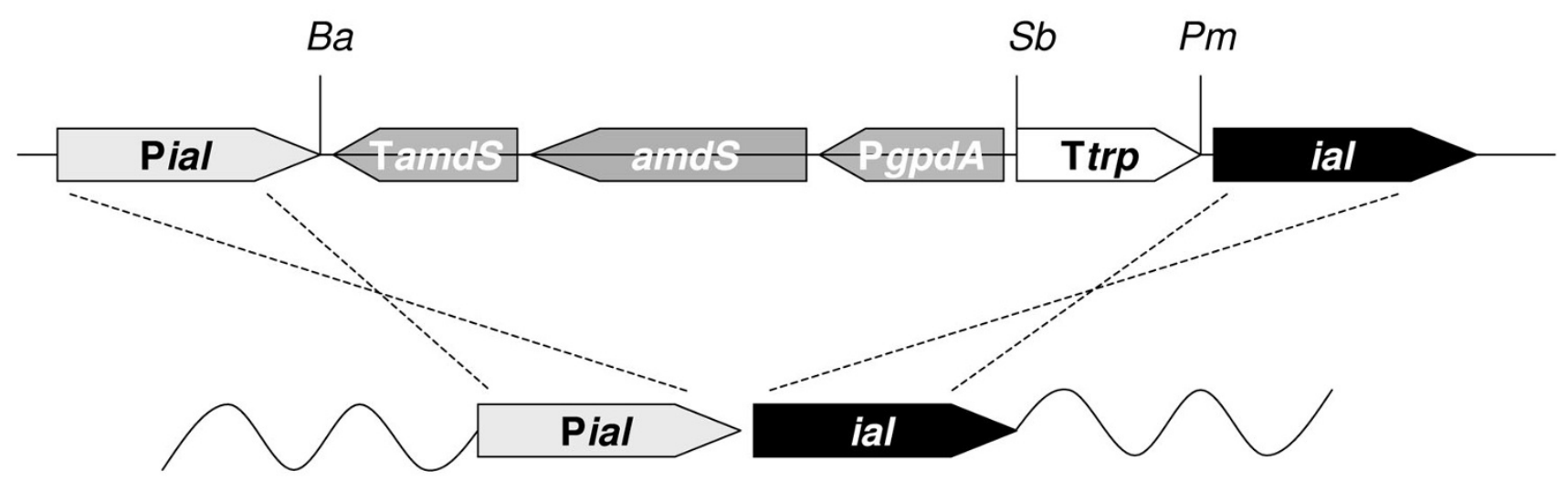

Figure 2

Generation of the ial null mutant in P. chrysogenum. The transcription of the ial gene was blocked by insertion (double crossover; dashed lines) of the amdS selection marker in opposite orientation between the ial gene promoter and the ial ORF. Restriction enzymes indicated: Ba, BamHI; Sb, Sbfl; Pm, Pmel. 
A

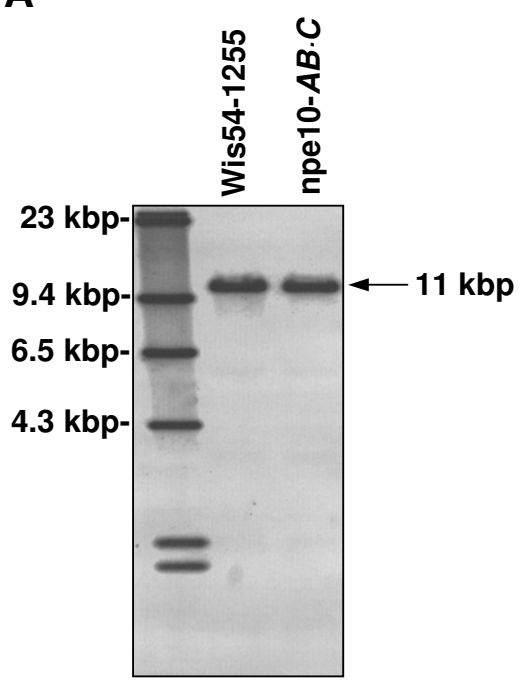

C

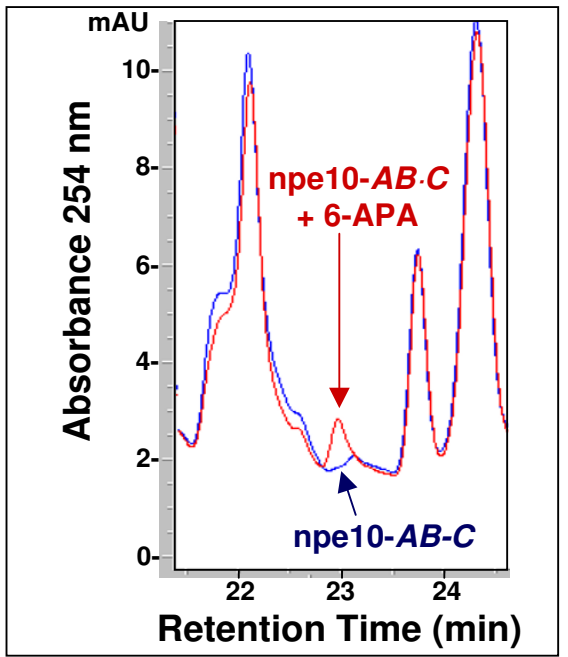

B

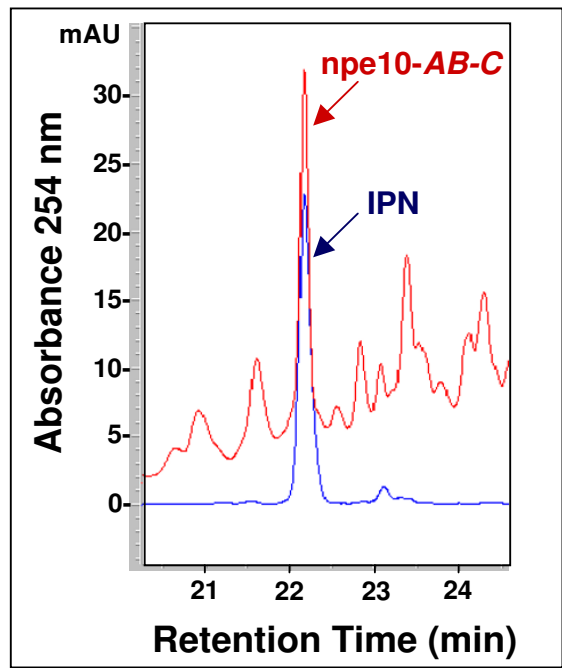

D

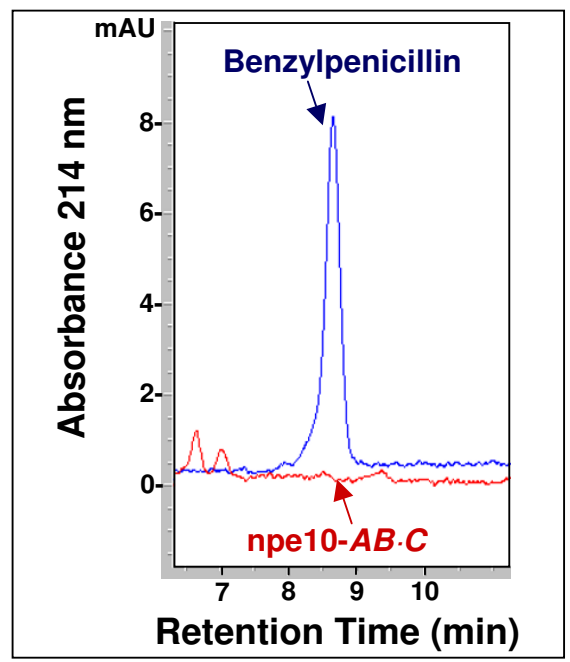

E

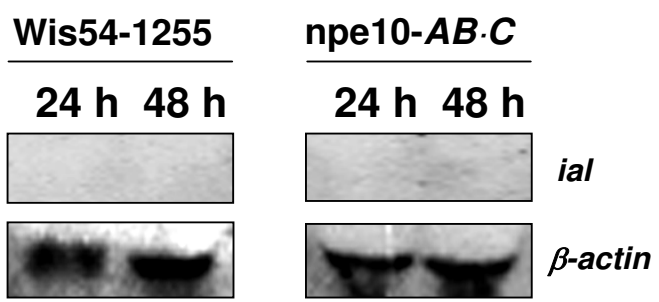

Figure 3

Characterization and expression of the ial gene and in vivo activity of the IAL in P. chrysogenum. (A) Southern blotting carried out with genomic DNA extracted from the npe-IO-AB.C and Wis54-I255 strains and digested with HindllI. The ial gene was used as probe. (B) HPLC analysis confirming the production of IPN by the npe I0-AB.C strain. (C) Chromatogram showing the lack of 6-APA production in the npe I0-AB.C strain. (D) Chromatogram showing the lack of benzylpenicillin production in the npe I0-AB.C strain. (E) Northern blot analysis of the ial gene expression in npe-I0-AB.C and Wis54-I255 strains. Expression of the $\beta$-actin gene was used as positive control. 
pressed using the strong $g d h$ gene promoter. With this purpose, plasmid p43gdh-ial was co-transformed with plasmid pJL43b-tTrp into the $P$. chrysogenum npe10-AB $C$ strain. Transformants were selected with phleomycin. Five randomly selected transformants were analyzed by PCR (data not shown) to confirm the presence of additional copies of the ial gene in the $P$. chrysogenum npe10-AB $C$ genome. Integration of the Pgdh-ial-Tcyc1 cassette into the transformants of the npe $10-A B \cdot C$ strain was confirmed by Southern blotting (Fig. 4A) using the complete ial gene as probe (see Methods). Transformants T1, T7 and T72 showed the band with the internal wild-type ial gene (11 $\mathrm{kb}$ ) plus a 2.3-kb band, which corresponds to the whole Pgdh-ial-Tcyc1 cassette. Densitometric analysis of the Southern blotting revealed that 1 copy of the full cassette was integrated in transformant $\mathrm{T} 1$, and 3-4 copies in transformants T7 and T72. Additional bands, which are a result of the integration of incomplete fragments of this cassette, were also visible in these transformants. Transformant T7 was randomly selected and expression of the ial gene was confirmed by northern blotting using samples obtained from mycelia grown in CP medium (Fig. $4 \mathrm{~B})$. This transformant was named $P$. chrysogenum npe10$A B \cdot C \cdot$ ial.

IPN amidohydrolase (6-APA forming) and IPN acyltransferase (benzylpenicillin forming) activities were tested in this strain under the same conditions used for the northern blot analysis. The npe10-AB $C \cdot D E$ strain is a derivative of $P$. chrysogenum npe $10-A B \cdot C$ that expresses the penDE gene and has IAT activity [11] and it was used as positive control. Neither 6-APA (Fig. 4C) nor benzylpenicillin (Fig. 4D) were detected in samples taken at $48 \mathrm{~h}$ and $72 \mathrm{~h}$ from cultures of the transformant $\mathrm{T} 7$ grown in $\mathrm{CP}$ medium with or without phenylacetic acid, whereas high penicillin production was observed in the control npe10$A B \cdot C \cdot D E$ strain. This indicates that the IAL protein is not involved in the biosynthesis of penicillin or 6-APA.

\section{Overexpression of the ialARL gene containing a modified peroxisomal targeting sequence in the $P$. chrysogenum npe I $0-A B \cdot C$ strain}

One important question is whether the absence of the canonical PTS1 sequence (ARL) at the C-terminal end of the IAL protein and the subsequent mislocalization outside the peroxisomal matrix, is responsible for the lack of activity. Hence, site-directed mutagenesis of the ial gene was performed (see Methods) in order to replace the three last amino acids of the IAL protein with the motif ARL. The new construct, p43gdh-ial ${ }^{A R L}$ was co-transformed together with plasmid pJL43b-tTrp into the P. chrysogenum npe10- $A B \cdot C$ strain and transformants were selected with phleomycin. Five randomly selected transformants were analyzed by PCR to confirm the presence of additional copies of the ial ${ }^{A R L}$ gene in the P. chrysogenum npe10-AB $C$ genome (data not shown). Integration of the Pgdh-ialARL Tcyc1 cassette into the npe $10-A B \cdot C$ strain was confirmed in these transformants by Southern blotting (Fig. 5A), using the complete ial gene as probe. Transformants T1 and T35 showed the band with the internal wild-type ial gene $(11 \mathrm{~kb})$ plus a $2.3 \mathrm{~kb}$ band, which corresponds to the whole Pgdh-ial ${ }^{A R L}$-Tcyc1 cassette. Additional bands, which are a result of the incomplete integration of this cassette, were also visible in transformant T35. Densitometric analysis of the Southern blotting revealed that 1-2 copies of the full cassette had integrated in transformant T1, and 23 copies in transformants T35. Transformant T1 was selected (hereafter named $P$. chrysogenum npe10$A B \cdot C \cdot i^{A R L}$ ) and expression of the ial ${ }^{A R L}$ gene was confirmed by northern blotting using samples obtained from mycelia grown in CP medium (Fig. 5B). IPN amidohydrolase and IPN acyltransferase activities were tested under the same conditions used for the northern blot analysis (cultures in CP medium with or without phenylacetic acid). Neither 6-APA (Fig. 5C) nor benzylpenicillin (Fig. $5 \mathrm{D})$ were detected at any time, indicating that the IAL ${ }^{\mathrm{ARL}}$ protein is not able to convert IPN into 6-APA or benzylpenicillin even when the PTS1 targeting signal is present.

\section{Overexpression of the cDNA of the ial gene in E. coli. The IAL is self-processed, but lacks in vitro phenylacetyl-CoA: 6-APA acyltransferase activity}

In order to analyse the IAL processing and in vitro activity, the cDNA of the ial gene obtained by RT-PCR as indicated in Methods was overexpressed in E. coli JM109 (DE3). One 1089-bp band was amplified (Fig. 6A) and sequenced. Two introns were identified within this gene by comparison of this sequence with the gDNA of the ial gene. Intron 1 (61 bp) spanned nucleotides at positions 52-112 of the gDNA, whereas intron 2 (60 bp) spanned positions 518-577 of the gDNA. The cDNA of the ial gene was overexpressed using plasmid pULCT-ial (see Methods and Fig. 6B). As shown in Fig. 6C, one 40-kDa protein, coincident with the size estimated for the unprocessed IAL protein, was obtained at $37^{\circ} \mathrm{C}$. This protein was present in insoluble aggregates forming inclusion bodies. The authenticity of this protein was confirmed by MALDI-TOF peptide mass spectrometry. To test the processing of this protein, the ial gene was overexpressed at $26^{\circ} \mathrm{C}$, a temperature that is optimal for IAT folding and processing in $E$. coli $[26,31]$. At this temperature self-processing occurred; no traces of the $\sim 40$-Da band were visible and the $\sim 28$ $\mathrm{kDa}$ and $12 \mathrm{kDa}$ subunits were obtained in the soluble extracts of E. coli (Fig. 6D). We confirmed the processing through the analysis of the $\sim 28-\mathrm{kDa}$ subunit by peptide mass fingerprinting. This peptide was identified as the $\mathrm{C}$ terminal part of the IAL, evidencing that the IAL protein, like the IAT, also undergoes a phenomenon of selfprocessing. 
A
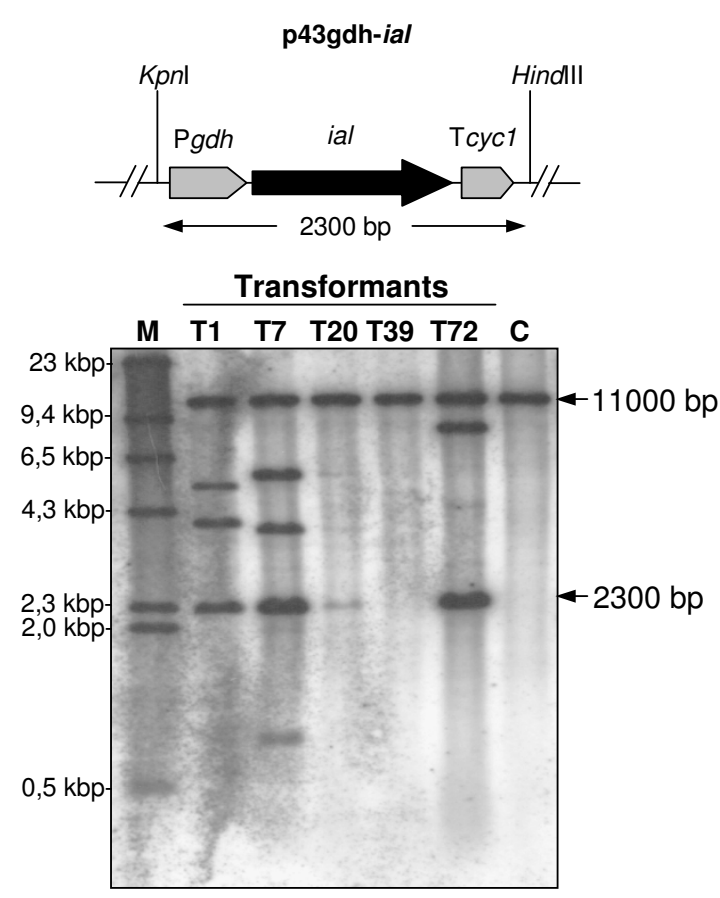

B

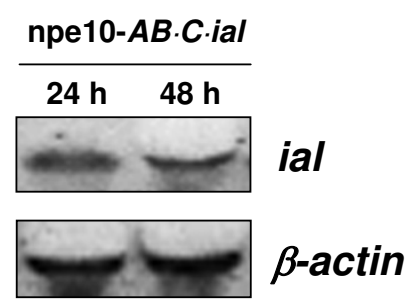

C

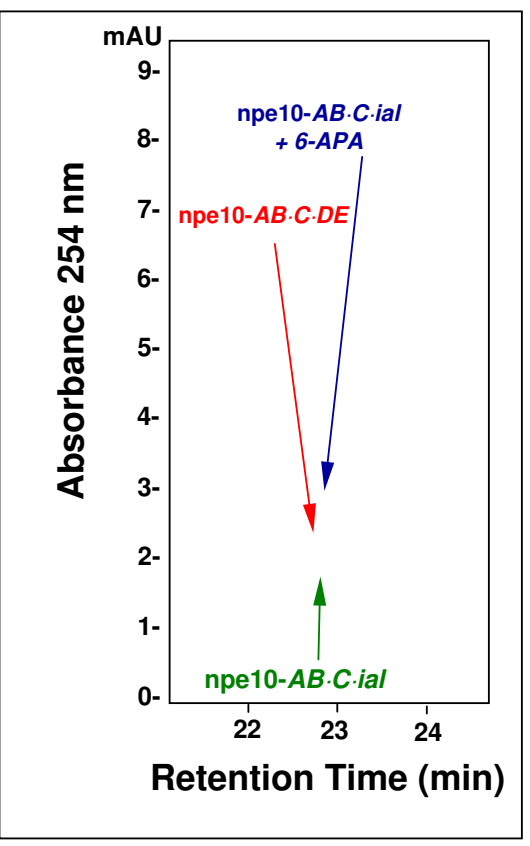

D

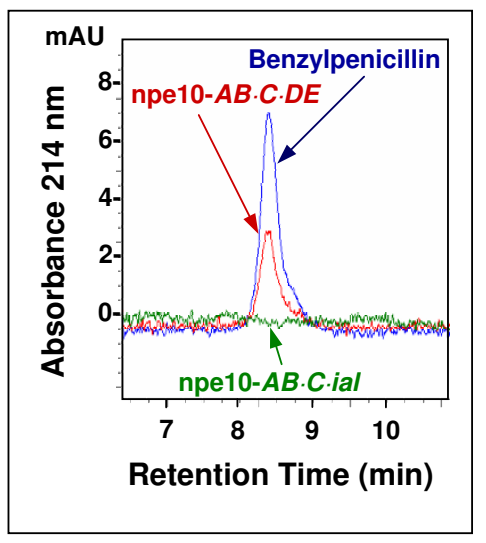

\section{Figure 4}

Overexpression of the ial gene in the $P$. chrysogenum npe $10-A B \cdot C$ strain. $(A)$ The npe $10-A B \cdot C$ strain was co-transformed with plasmids p43gdh-ial and the helper pJL43b-tTrp. Different transformants were randomly selected (TI, T7, T20, T39 and T72) and tested by Southern blotting after digestion of the genomic DNA with Hindlll and Kpnl. These enzymes release the full Pgdh-ial-Tcycl cassette $(2.3 \mathrm{~kb})$ and one II.0-kb band, which includes the internal wild-type ial gene. Bands of different size indicate integration of fragments of the Pgdh-ial-Tcycl cassette in these transformants. Genomic DNA from the npe I $0-A B \cdot C$ strain $[C]$ was used as positive control. The $\lambda$-Hindll molecular weight marker is indicated as $M$. (B) Northern blot analysis showing the expression of the ial gene in transformant T7 (npe l0-AB.C.ial strain). Expression of the $\beta$-actin gene was used as control. (C) Representative chromatogram of the HPLC analysis of the production of 6-APA by the npe I0-AB.C.ial strain. The npe I0-AB.C.DE strain was used as positive control. As internal control, 6-APA was added to the samples obtained

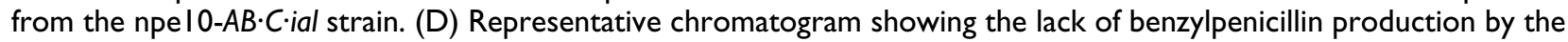
npe I $0-A B \cdot C \cdot i a l$ strain. Filtrates obtained from the npe I0-AB $C \cdot D E$ strain and a sample of pure potassium benzylpenicillin were used as positive controls. 
Once processing was confirmed, in vitro activity of the processed IAL protein was assessed (see Methods) using the soluble extracts of $E$. coli obtained after the overexpression of the ial gene at $26^{\circ} \mathrm{C}$. As positive control, soluble extracts containing the functional processed IAT, obtained from E. coli after overepression of the cDNA of the wildtype penDE gene at $26^{\circ} \mathrm{C}$ (using plasmid pPBC $\alpha \beta$ as indicated in Methods), were used. Benzylpenicillin formation was tested by bioassay as indicated in Methods. As shown in Fig. 6E, benzylpenicillin was only synthesized in the protein extracts containing the processed wild-type IAT, but not in extract of the processed IAL. This confirms that under in vitro conditions, the IAL protein also lacks enzymatic activities related to the biosynthesis of benzylpenicillin, despite the correct self-processing.

\section{Discussion}

The penicillin biosynthetic pathway has been largely elucidated [14,32]. In addition to the three main enzymes involved in this process (ACVS, IPNS and IAT), other ancillary proteins are also required, such as a phenylacetyl-CoA ligases, which primes (activates) the aromatic side chain $[4,5]$ and the phosphopantetheinyl transferase (PPTase), which activates the ACVS and is essential for penicillin biosyntheis in P. chrysogenum [33]. The origin of the pen gene cluster is intriguing, as occurs with the clusters of other fungal secondary metabolites $[12,34]$. The first two genes $(p c b A B, p c b C)$ of the penicillin pathway seem to originate from $\beta$-lactam producing bacteria [13], whereas the third gene (penDE) encoding the IAT that contains three introns, has been recruited from an ancestral fungal gene [12]. As reported here, in silico analysis of the $P$. chrysogenum genome identified a gene (ial) paralogue of the penDE gene [27] that encodes a protein with high similarity to IAT and is present in most of the genomes of ascomycetes.

We have shown in this work that the ial gene is expressed very poorly or not expressed at all in several $P$. chrysogenum strains and that generation of ial null mutants does not affect penicillin production. In addition, the ial gene in the npe10-AB $C$ strain has undergone a point mutation at nucleotide 980 (C to T). After CDNA sequence analysis, this point mutation introduces a stop codon after residue 286 , which gives rise to a shorter protein (286 amino acids instead of 362) in the npe10-AB $C$ strain. The lack of activity of the IAL present in this strain might be a consequence of the formation of a truncated version derived from the point mutation, but the fact that after overexpression of the ial gene (without the point mutation), the IAL protein still lacks both the IPN amidohydrolase and IPN acyltransferase activities in vivo, excludes this possibility.

Due to the high homology existing between the IAT and IAL proteins we wondered about the reason for the lack of activity in the IAL. The first possible cause was the absence of the PTS1 peroxisomal targeting motif and the consequent putative mislocalization of the IAL. However, when the PTS1 was added to the $\mathrm{C}^{\prime}$ end of the IAL, this protein was unable to produce 6-APA or benzylpenicillin in vivo. Strikingly, it has been recently reported that expression of the ial gene homologue in A. nidulans (named aatB) is easily detected and the protein encoded by this gene contributes to penicillin biosynthesis [35]. The A. nidulans aatBencoded IAL homologue also lacks the canonical PTS1 signal at the $\mathrm{C}^{\prime}$ end, although it is active, indicating that either there might be cryptic PTS1 sequences within this protein as it has been reported in literature [36], or the enzyme is active in the cytosol. The latter possibility is more likely, since addition of the PTS1 signal to the aatBencoded IAL homologue led to an increase in the penicillin titres [35].

The wild-type IAT is only active when it is self-processed into the $\alpha(11.5 \mathrm{kDa}$, pI: 7.24$)$ and $\beta(28.5 \mathrm{kDa}, \mathrm{pI}: 6.34)$ subunits $[20,26,31]$. It is well known that the P. chrysogenum and $A$. nidulans IATs differ in their ability to maintain the $40-\mathrm{kDa} \alpha-\beta$ heterodimer in an undissociated form [31]. Whereas the P. chrysogenum proIAT undergoes a quick and efficient self-processing, the A. nidulans proIAT remains partially undissociated. This difference in the processing rate of proIAT is responsible, among other reasons, for the low levels of benzylpenicillin production in A. nidulans (30-fold less than in wild-type P. chrysogenum NRRL1951). We have reported in a previous work that unprocessed proIAT molecules exert a regulatory role generating slow-processing molecules of IAT, thus decreasing the amount of the active form and the penicillin biosynthetic activity [26]. Therefore, the lack of IAL processing might be another explanation for its lack of activity in $P$. chrysogenum. However, when we analysed the sequence of this protein, we found that the $\mathrm{G} 102-\mathrm{C} 103$ processing site of IAT is conserved in the IAL (G105-C106). Self-processing of the IAL was confirmed by MALDI-TOF peptide mass spectrometry after SDS-PAGE analysis of the IAL synthesized in E. coli at $26^{\circ} \mathrm{C}$. This indicates that the IAL, like the IAT, belongs to the NTN family of proteins, which are capable of self-activation, as it occurs with other NTN amidohydrolases [23,37]. Despite the proper processing, in vitro phenylacetyl-CoA: 6-APA acyltransferase activity was not detected, proving that misprocessing is not responsible for the lack of activity.

A detailed analysis of the IAL sequence showed that the amino acid equivalent to the S309 in the IAT, which has been reported to be required for enzyme activity [38], is not conserved in the IAL of $P$. chrysogenum (this amino acid has been replaced by N323). However, in the IAL homologue of $A$. nidulans the amino acid equivalent to the S309 is conserved, indicating that this might be the 


\section{A}
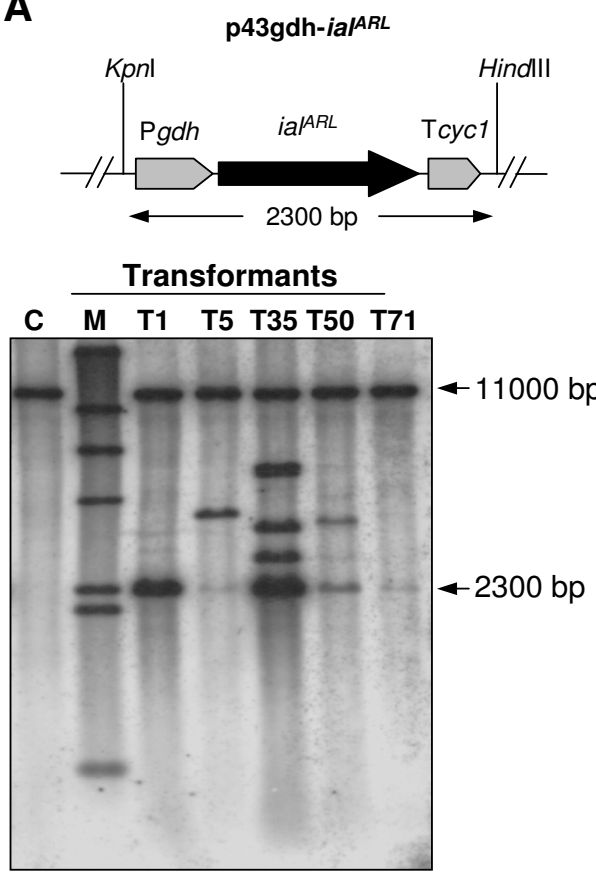

C

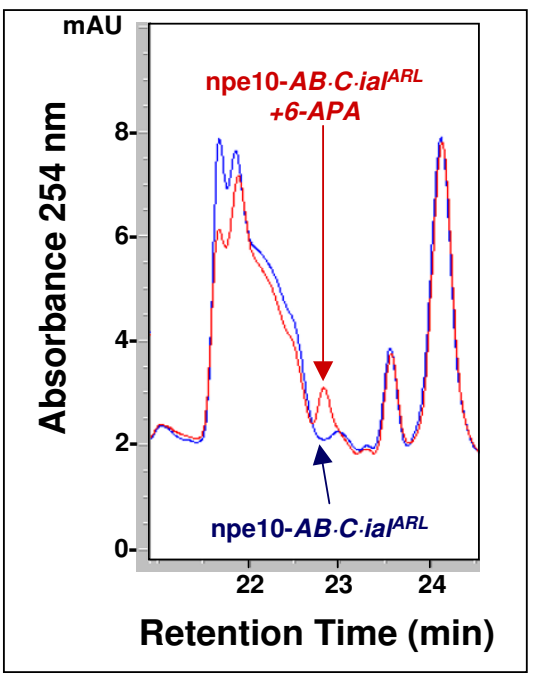

B

D
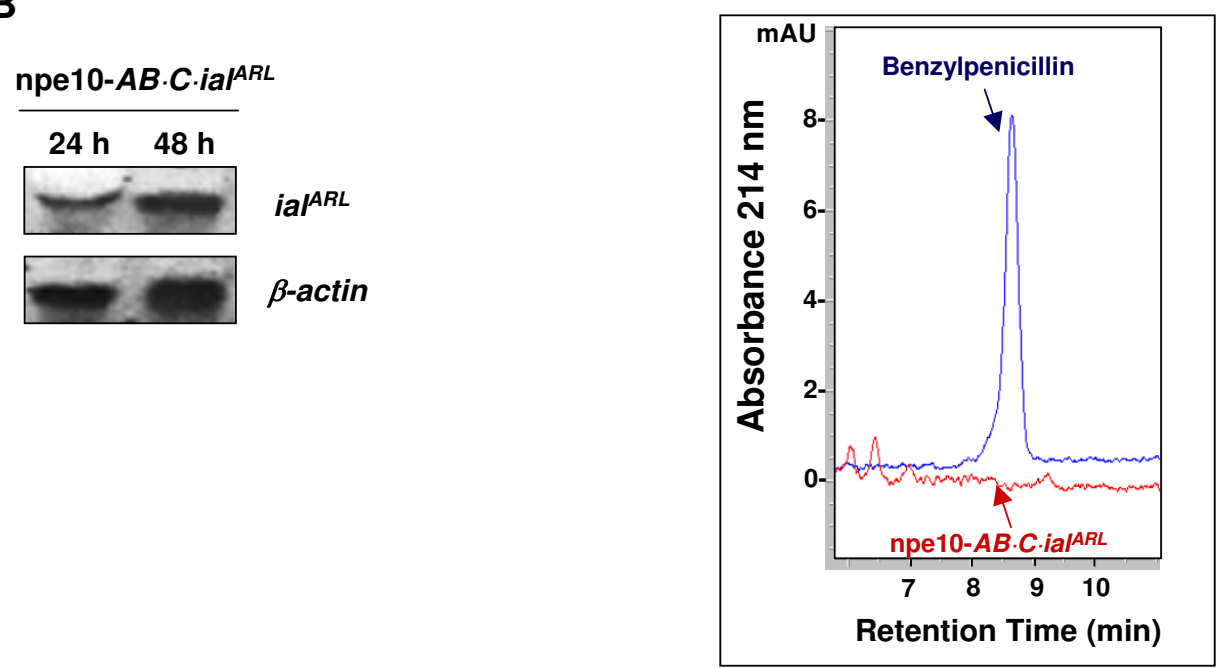

\section{Figure 5}

Overexpression of the ial ${ }^{A R L}$ gene in the $\boldsymbol{P}$. chrysogenum npe $\mathbf{0} \mathbf{0}-\boldsymbol{A B} \cdot \boldsymbol{C}$ strain. (A) The npe $10-A B \cdot C$ strain was co-transformed with plasmids p43gdh-iaARL and the helper pJL43b-tTrp. Different transformants were randomly selected (TI, T5, T35, T50 and T7I) and tested by Southern blotting after digestion of the genomic DNA with Hindlll and Kpnl. These enzymes release the full Pgdh-ialARL-Tcycl cassette $(2.3 \mathrm{~kb})$ and one II.0-kb band, which includes the internal wild-type ial gene. Bands of different size indicate integration of fragments of the Pgdh-ialARL-Tcycl cassette in these transformants. Genomic DNA from the npe I $0-A B \cdot C$ strain $[C]$ was used as positive control. The $\lambda$-Hindll molecular weight marker is indicated as $M$. (B) Northern blot analysis showing the expression of the ialARL gene in transformant TI (npel0-AB.C.ial ${ }^{A R L}$ strain). Expression of the $\beta$-actin gene was used as positive control. (C) Representative chromatogram of the HPLC analysis of the production of 6-APA by the npel $0-A B \cdot C \cdot$ ialARL strain. As internal control, 6-APA was added to the samples obtained from the npe I $0-A B \cdot C \cdot$ ialARL strain. (D)

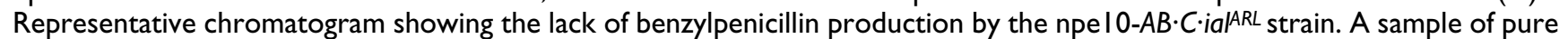
potassium benzylpenicillin was used as positive control. 
A

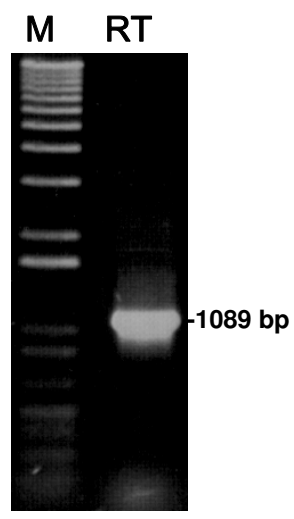

C

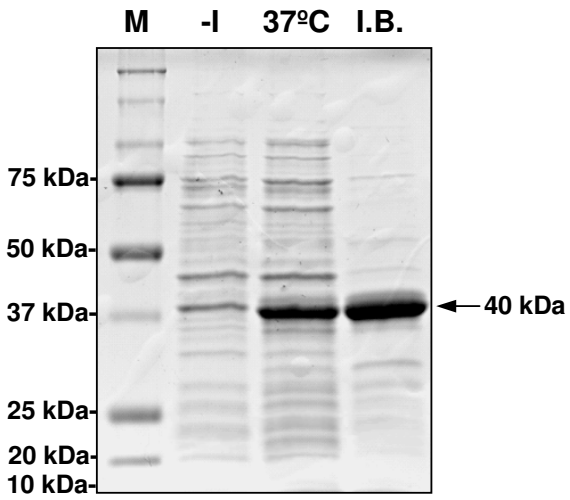

B

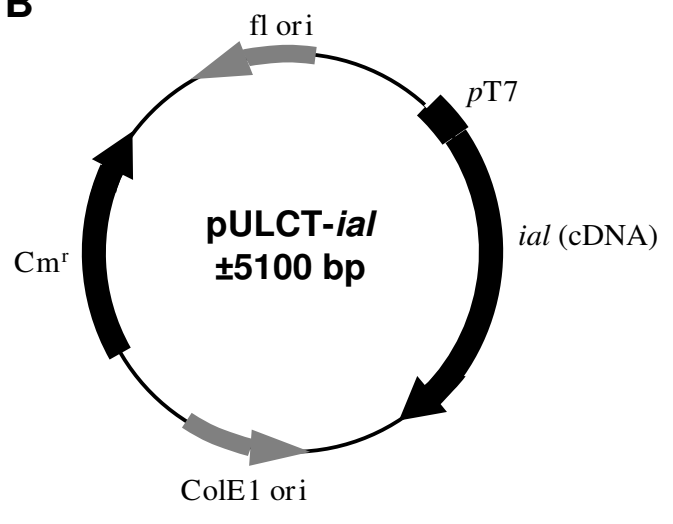

D

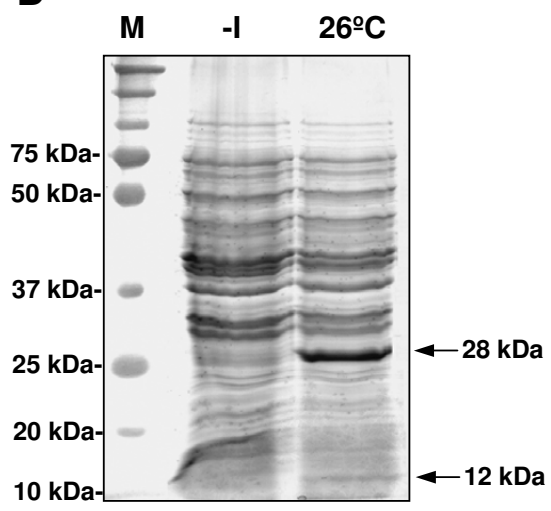

E

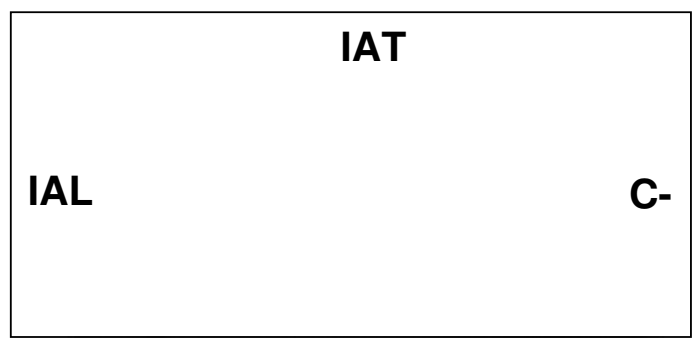

\section{Figure 6}

Characterization of the recombinant IAL in E. coli. (A) Agarose gel electrophoresis of the CDNA of the ial gene obtained by RT-PCR (RT). The I-kb Ladder plus molecular marker (Invitrogen) is indicated as M. (B) Schematic representation of plasmid pULCT-ial. (C) SDS-PAGE showing the overexpression of the ial gene in $E$. coli at $37^{\circ} \mathrm{C}$. M: molecular mass marker; -I: uninduced cells; $37^{\circ} \mathrm{C}$ : total cell extracts obtained after a $5 \mathrm{~h}$-induction with IPTG at $37^{\circ} \mathrm{C}$; I.B.: inclussion bodies obtained after a 5 h-induction with IPTG at $37^{\circ} \mathrm{C}$. (D) SDS-PAGE showing the overexpression of the ial gene in E. coli at $26^{\circ} \mathrm{C}$. M: molecular mass marker; -I: uninduced cells; $26^{\circ} \mathrm{C}$ : soluble cell extracts obtained after a $5 \mathrm{~h}$-induction with IPTG at $26^{\circ} \mathrm{C}$. Note the lack of the $40-\mathrm{kDa}$ band and the presence of the $28-\mathrm{kDa}$ band. (E) Biossay carried out to determine the in vitro phenylacetylCoA: 6-APA acyltransferase activity (see Methods) present in the soluble extracts of $E$. coli overexpressing either the ial (IAL) or the penDE (IAT) genes. As a negative control, the reaction mixture was used without the addition of soluble extracts from E. coli overexpressing the penDE gene (C-). 


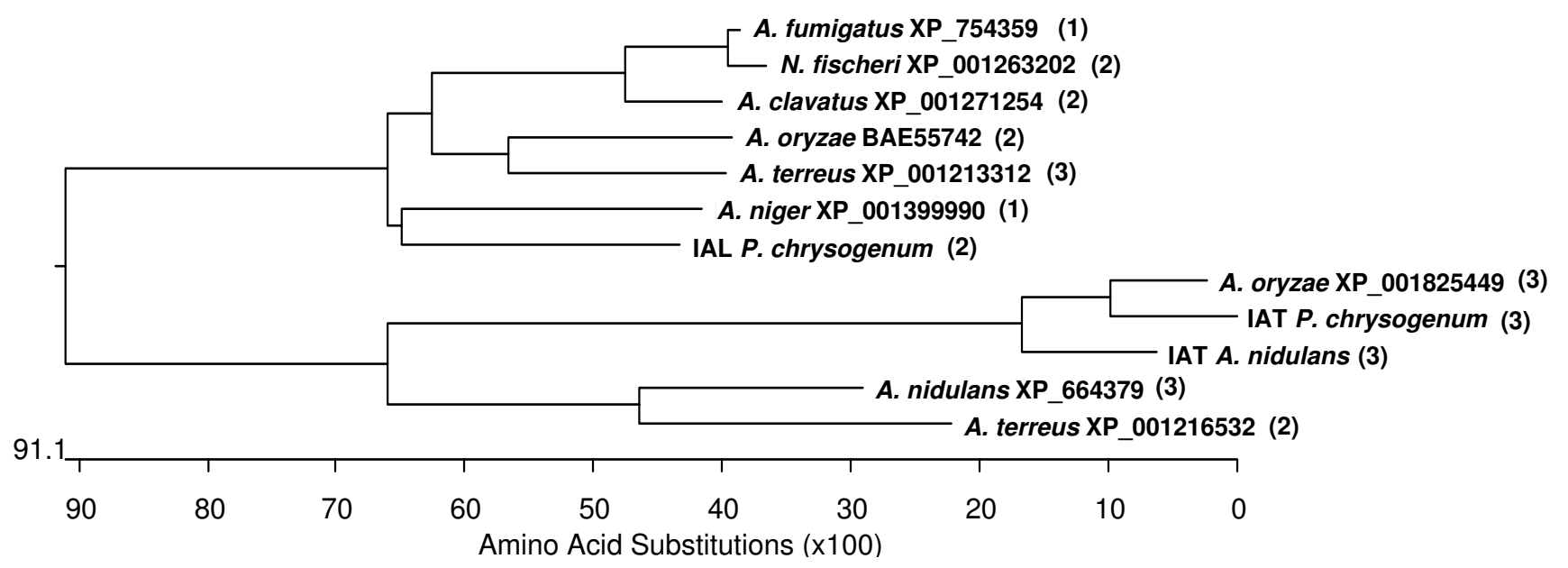

\section{Figure 7}

Phylogenetic tree showing the evolutive distances amongst IATs and putatives IALs from several ascomycetes. The IAT of P. chrysogenum (GenBank: PI 5802), the IAT of A. nidulans (GenBank: P2II33) and a hypothetical protein of A. oryzae which shares $84 \%$ identity with the P. chrysogenum IAT (GenBank: XP 00I825449), were compared to the P. chrysogenum IAL and putative homologues of this protein that are present in different ascomycetes, such as $A$. oryzae (GenBank: BAE55742), A. clavatus (GenBank: XP 00127/254), A. niger (GenBank: XP 001399990), A. terreus (GenBank: XP 00I2I33I2 and XP 001216532), N. fischeri (GenBank: XP 001263202), A. fumigatus (GenBank: XP 754359) and A. nidulans (aatB-encoded protein GenBank: XP 664379). Sequences were aligned using the MegAlign program (Lasergene, DNASTAR, Inc.). Intron content of the genes encoding these proteins is indicated in brackets.

main reason for the disparity in enzyme activity between the IALs of these two fungi. The S309 is part of the GXS ${ }^{309}$ XG motif present in the P. chrysogenum and A. nidulans IATs and has been previously proposed to be involved in cleavage of phenylacetyl-CoA and binding of the phenylacetyl moiety to form acyl-enzyme molecules $[21,31]$. The formation of phenylacetyl-enzyme and other acyl-enzyme molecules has been confirmed in the IAT by mass spectrometry [39]. Although the A. nidulans IAL does not exactly contain the GXSXG motif, the presence of the Ser272, equivalent to the Ser309, may be sufficient for the activity of this enzyme.

The availability of the genome of several ascomycetes has revealed the presence of $i a l$ gene homologues in penicillin and non-penicillin producing fungi, whereas the penDE gene homologues are only found in penicillin-producing fungi, such as A. nidulans and A. oryzae. This might indicate that during evolution, a single ancestral gene was duplicated, giving rise to the penDE (or aatA) gene and its paralogue, the ial gene (initially encoding a NTN amidohydrolase not active in $P$. chrysogenum and with low activity in A. nidulans). The P. chrysogenum IAL and related proteins in other fungi form a separate evolutive clade from IATs (Fig. 7), indicating that they evolved separately. This hypothesis is supported by the presence of duplicated genes encoding putatives IAT and IAL homologues in $A$. oryzae, which also contains the penicillin gene cluster.
From those ascomycetes containing this cluster, only $A$. nidulans has an IAL homologue (GenBank: XP_664379) more closely related to IATs, a fact that may explain the presence of penicillin biosynthetic activity in this protein.

Genes encoding IATs in P. chrysogenum, A. nidulans and A. oryzae contain three introns, thus differing from those genes encoding IAL and IAL-homologues (Fig. 7). Only the aat $B$ gene encoding the $A$. nidulans IAL homologue and one of the A. terreus ial gene homologue (GenBank: XP 001213312), contain three introns. This suggests that alternatively, ial and ial gene homologues might have had a different origin from the IAT-encoding genes (penDE or aat $A$ genes), thus encoding proteins with a different function as it was confirmed by the lack of penicillin biosynthetic activity of the $P$. chrysogenum IAL. With this hypothesis, only the aat $B$ gene from $A$. nidulans would be a real paralogue of the IAT-encoding gene (aatA) formed by gene duplication from a common ancestor. This is supported by the presence of penicillin forming activity of the aatB-encoded IAL homologue and by the presence of the same transcription factors binding to the promoter regions of these two genes [35].

\section{Conclusion}

If there was a common ancestor for the ial and penDE genes, most of the Ascomycota fungi initially had the potential capacity to perform the acyltransferase reaction. However, 
only a few of them, like A. nidulans and P. chrysogenum, were able to develop during evolution, the penDE encoding the highly functional IAT enzyme. The penDE gene was linked to the first two genes (of bacterial origin) of the penicillin pathway, which endowed these microorganisms with an important ecological advantage because of the ability to generate aromatic penicillins. It is likely that the de novo formation of this cluster occurred in a common ancestor of the genera Penicillium and Aspergillus, since the pen cluster is present in several species of those genera [40-42]. However, not all genomes of the aspergilli contain the pen cluster; e.g., A. fumigatus lacks it, although it contains the ial gene. This indicates that the pen cluster might have been horizontally transferred only to some species of the genus, or alternatively, the primitive pen cluster might have been lost during subsequent evolution.

\section{Methods}

\section{Fungal strains and culture conditions}

P. chrysogenum NRRL 1951, the natural isolate obtained from an infected cantaloupe [43] was used as wild-type strain. $P$. chrysogenum Wis54-1255, which contains a single copy of the penicillin gene cluster [6], was used as parental strain. P. chrysogenum npe10-AB $C$ [11], a derivative of the npe10 $\mathrm{pyrG}^{-}$ strain ( $\triangle$ pen) $[9,10]$ complemented with the $p c b A B$ and $p c b C$ genes was used in the molecular analysis of IAT. $P$. chrysogenum DS54465 strain, a derivative of DS17690 [28] wherein the P. chrysogenum KU70 homologue has been deleted (Marco A. van den Berg, unpublished results), were used in the ial gene deletion experiments.

Fungal spores were collected from plates in Power medium [44] grown for 5 days at $28^{\circ} \mathrm{C}$. P. chrysogenum liquid cultures were initiated by inoculating fresh spores in complex medium CIM (20 g/l corn steep solids, $10 \mathrm{~g} / \mathrm{l}$ yeast extract, $58 \mathrm{mM}$ sucrose, $50 \mathrm{mM}$ calcium carbonate, pH 5.7) or defined DP medium [44] without phenylacetate. After incubation at $25^{\circ} \mathrm{C}$ for $20 \mathrm{~h}$ in an orbital shaker $(250 \mathrm{rpm})$, aliquots were inoculated in complex penicillin production CP medium ( $4 \mathrm{~g} / \mathrm{l}$ potassium phenylacetate, $20 \mathrm{~g} / \mathrm{l}$ pharmamedia, $50 \mathrm{~g} / \mathrm{l}$ lactose, $0.03 \mathrm{M}$ ammonium sulphate, $0.05 \mathrm{M}$ calcium carbonate, $\mathrm{pH}$ 6.6) or in defined DP medium with or without phenylacetate $(4 \mathrm{~g} / \mathrm{l})$.

Spores of the ial null mutant were used to inoculate shake flasks with synthetic media supporting $\beta$-lactam production [45]. To verify the validity of the findings, two different penicillin side chain precursors were added to the media, phenyl acetic acid and adipate, at 0.3 and $0.5 \mathrm{~g} / \mathrm{l}$ respectively. Cultivation was for 168 hours at $25^{\circ} \mathrm{C}$ and $280 \mathrm{rpm}$. As controls both parent strains, DS17690 and DS54465, were used.

\section{Plasmid constructs}

To completely block the transcription of the ial gene, 1500 base pairs of the promoter and the ORF were PCR ampli- fied (for oligonucleotides see the Appendix) and fused to the amdS selection marker, obtained from PHELY-A1 [46] by PCR amplification (Fig. 2). To block eventual read trough from any unconventional transcription start sites in the amdS gene, the trp terminator was PCR amplified from plasmid pAMPF21 [47] and inserted between the amdS gene and the ial ORF (Fig. 2).

Plasmid p43gdh-ial was constructed to overexpress the ial gene in $P$. chrysogenum starting from plasmid pIBRC43BglII, a derivative of pIBRC43 [48] that contains the $\mathrm{NcoI}$ restriction site mutated to BglII. The ial gene was amplified from genomic $P$. chrysogenum Wis54-1255 DNA using the primers DElikeF and DElikeR (see the Appendix) and was cloned in the BglII-StuI sites of plasmid pIBRC43BglII, between the A. awamori gdh gene promoter (a very efficient promoter in ascomycetes) and the Saccharomyces cerevisiae cyc1 transcriptional terminator.

Plasmid p43gdh-ial ${ }^{A R L}$ is a derivative of plasmid p43gdh$i a l$ and was constructed to overexpress the $i a l^{A R L}$ gene in $P$. chrysogenum. This gene includes the sequence encoding the PTS1 (peroxisomal targeting sequece) motif "ARL" at the 3' end, which was introduced using the "QuikChange ${ }^{\circledast}$ Site-Directed Mutagenesis Kit" (Stratagene La Jolla, CA, U.S.A.) following the manufacturer's instructions. Plasmid p43gdh-ial was used as template in the PCR reaction performed with HPLC-purified primers ARLF and ARLR (Appendix).

Plasmid pJL43b-tTrp, which contains the ble gene (for bleomycin/phleomycin resistance) and the transcriptional terminator of the A. nidulans $\operatorname{trpC}$ gene, was co-transformed with either p43gdh-ial or p43gdh-ial ${ }^{A R L}$ into the Wis54-1255 strain.

Plasmid pPBC $\alpha \beta$ has been previously described $[26,31]$ and was used to overexpress the cDNA of the penDE gene in E. coli.

Plasmid pULCT-ial is a derivative of plasmid pULCT $\alpha \beta$ [31] and was used to overexpress the ial gene in E. coli. It was constructed as follows: The cDNA of the ial gene was amplified by RT-PCR using primers cDElikeF and DelikeR (Appendix). The RT-PCR product was digested with those endonucleases and subcloned into plasmid pULCT $\alpha \beta$, which was previously digested with HindIII, blunt-ended and finally digested with NdeI.

\section{Transformation of $\mathbf{P}$. chrysogenum protoplasts}

Protoplasts were obtained and transformed as previously described $[49,50]$. Selection of transformant clones was performed by resistance to phleomycin $(30 \mu \mathrm{g} / \mathrm{ml})$. Selection of acetamide-consuming transformants was done as described previously [51]. 
DNA and RNA isolation, Southern and northern blotting DNA and RNA isolation, Southern and northern blotting were carried out as described before [7]. The ial gene was used as probe. The signal provided by the Southern blotting was quantified by densitometry using the "Gel-Pro Analizer" software (Media Cybernetics).

\section{Intron analysis}

Identification of introns in the ial gene was performed by RT-PCR using the "OneStep RT-PCR Kit" (Qiagen, Hilden, Germany) following the manufacturer's instructions. Total RNA was extracted from mycelia of the npe10$A B \cdot C \cdot$ ial strain grown for $48 \mathrm{~h}$ in CP medium, using the "RNeasy Mini Kit" columns (Qiagen) following the manufacturer's instructions. RNA was treated with RQ1 RNase-free DNase (Promega Corporation) following the manufacturer's instructions. Oligonucleotides cDElikeF and DElikeR (see the Appendix) were used for this purpose. The presence of introns was confirmed by sequencing.

\section{Derivatization of IPN and 6-APA and HPLC analysis}

Quantification of IPN and 6-APA in P. chrysogenum filtrates was carried out by HPLC as previously described [11].

\section{Extraction and HPLC analyses of penicillin from filtrates} Filtrates or cell extracts $(3 \mathrm{ml})$ were acidified until pH 2.0 with $0.1 \mathrm{~N} \mathrm{HCl}$. Benzylpenicillin was extracted by adding n-butyl acetate $(3 \times 1 \mathrm{ml})$ and re-extracted from the organic phase with $10 \mathrm{mM}$ phosphate buffer $\mathrm{pH} 7.5$ (3 $\times$ $1 \mathrm{ml}$ ). This procedure was performed at $4^{\circ} \mathrm{C}$. The aqueous phase was lyophilised and resuspended in $300 \mu$ l of Milli$\mathrm{Q}$ water for filtrates (in $100 \mu \mathrm{l}$ for intracellular extracts), which were analysed by HPLC. HPLC analysis of benzylpenicillin was performed in an Agilent 1100 HPLC system with an analytical $4.6 \times 150 \mathrm{~mm}(5 \mu \mathrm{m})$ ZORBAX Eclipse XDB-C18 column (Agilent Technologies), a flow rate of $1 \mathrm{ml} / \mathrm{min}$ and a detector wavelength of $214 \mathrm{~nm}$. Samples $(20 \mu \mathrm{l})$ were injected and eluted using as mobile phase Buffer A (30 mM ammonium formate $\mathrm{pH} 5.0$ and $5 \%$ acetonitrile) and Buffer $B$ (same as Buffer A plus acetonitrile $20: 80, \mathrm{v} / \mathrm{v}$ ) with an isocratic method ( $85 \%$ of $A$ ). Benzylpenicillin showed a retention time of $8.69 \pm 0.14$ min and its detection limit was $0.1 \mu \mathrm{g} / \mathrm{ml}$.

\section{NMR analyses of penicillin from filtrates}

Analysis of $\beta$-lactams produced by the ial null mutant was done by quantitative ${ }^{1} \mathrm{H}$ NMR at $600 \mathrm{MHz}$ on a Bruker Avance 600 spectrometer. To a known quantity of filtrate, a known quantity of internal standard (maleic acid), dissolved in phosphate buffer was added prior to lyophilisation. The residue was dissolved in $\mathrm{D}_{2} \mathrm{O}$ and measured at $300 \mathrm{~K}$. The delay between scans (30 s) was more than 5 times $\mathrm{T} 1$ of all compounds, so the ratio between the inte- grals of the compounds of interest and the integral of the internal standard is an exact measure for the quantity of the $\beta$-lactams.

\section{Overexpression of the penDE and ial genes in E. coli and SDS-PAGE of the proteins}

The penDE and ial genes were overexpressed in E. coli JM109 (DE3) cells using $0.5 \mathrm{mM}$ IPTG for $6 \mathrm{~h}$ at $26^{\circ} \mathrm{C}$. Protein samples to be analysed by SDS-PAGE were diluted in loading buffer (60 mM Tris- $\mathrm{HCl}$ pH 6.8, 2\% SDS, 100 mM DTT, $10 \%$ glycerol and $0.1 \%$ bromophenol blue), boiled for $5 \mathrm{~min}$, and run in a $12 \%$ acrylamide gel. The "Precision Plus Protein All Blue Standards" (Bio-Rad, Hercules, CA, USA), was used as molecular mass marker. Proteins were stained using Coomassie Brilliant Blue R250 dying.

\section{Determination of the in vitro phenylacetyl-CoA: 6-APA acyltransferase activity}

Measurement of the phenylacetyl-CoA: 6-APA acyltransferase activity in vitro was carried out using soluble extracts obtained from E. coli strains overexpressing either the penDE or the ial genes. Briefly, $72 \mu \mathrm{l}$ of cell extracts were mixed with $48 \mu \mathrm{l}$ of the reaction mixture $(0.1 \mathrm{M}$ Tris- $\mathrm{HCl}$ $\mathrm{pH}$ 8.0, $0.05 \mathrm{M}$ DTT, $0.2 \mathrm{mM}$ 6-APA and $0.2 \mathrm{mM}$ phenylacetyl-CoA) and incubated at $26^{\circ} \mathrm{C}$ for 15 minutes. The reaction was stopped with $120 \mu \mathrm{l}$ of methanol, centrifuged at $10,000 \times \mathrm{g}$ for 5 minutes and biossayed using Micrococcus luteus as test microorganism. Biossays were performed as previously described [26].

\section{Abbreviations}

6-APA: 6-amino penicillanic acid; ACV: $\delta$ (L- $\alpha$-aminoadipyl)-L-cysteinyl-D-valine; ACVS: $\delta$ (L- $\alpha$-aminoadipyl)cysteinyl-valine synthetase; amdS: acetamidase resistance gene; ble: bleomycin and phleomycin resistance gene; CIM: complex inocullum medium; $\mathrm{CP}$ : complex penicillim production medium; DP: defined medium; HPLC: high performance liquid chromatography; IAL: IAT-like; IAT: isopenicillin $\mathrm{N}$ acyltransferase; IPN: isopenicillin $\mathrm{N}$; IPNS: IPN synthase; LB: Luria-Bertani broth medium; NTN: N-terminal nucleophile; ORF: open reading frame; Pgdh: glutamate dehydrogenase gene promoter; PPTase: 4'-phosphopantetheinyl transferase; PTS1: peroxisomal targeting sequence type 1 ; RT-PCR: reverse transcriptionPCR; Tcyc1: cytochrome c1 transcriptional terminator; tTrp: tryptophan $\mathrm{C}$ biosynthesis gene transcriptional terminator.

\section{Authors' contributions}

CGE and JFM conceived the study and participated in its design. CGE performed the characterization and overexpression experiments. IV made the HPLC analysis of samples. RVU performed the ial transcriptional analysis. MAV and RALB carried out the ial null mutant experiments. All 
authors drafted the manuscript and JMF revised the article. All authors read and approved the final manuscript.

\section{Appendix}

Primers used in this work.

FWD-IAL-LF; 5'-ccttcgccgactgagtggcatgttgaaccaggacgcctacac-3'

REV-IAL-LF; 5'-cggcgctccaacgttgaggataattgctggtcctgtataatgtcagtacaaatacatc-3'

FWD-IAL-RF; 5'-atgtctgaaaacgagccaatcaagctggaactc-3'

REV-IAL-RF; 5'-ccttcgccgactgatggcttttgagctgaatacttgaagatggagtag-3'

FWD-amdS;

$5^{-}-$

ctggaattgtttaaacgcggccgccgcctgcaggataacttcgtatagcatacattat acgaagttatgactctttctggcatgcggagagac-3'

REV-amdS; 5'-atggatggatccataacttcgtataatgtatgctatacgaagttatgttgagtggtatggggccatcc-3'

FWD-TtrpC; 5'-cgaggagcacctgcaggccgacgccgaccaacaccgcc3'

REV-TtrpC; 5'-ccgccagtgtttaaactagcggccgcatggcgcgccgtattgggtgttacggagcattcac-3'

DElikeF; 5'-cattatacaggagatctatgtctgaaaac-3'

DElikeR; 5'-cagccgtctttcaaggccttcaccaggggat-3'

(The BglII and StuI restriction sequences are italicised)

ARLF; 5'-gaagggcctgtgttgacagccaggctttgaaggcctcggagatcc-3'

ARLR; 5'-ggatctccgaggccttcaaagcctggctgtcaacacaggcccttc-3'

(The sequence encoding the ARL motif is italicised)

cDElikeF; 5'-caggagacatatgtctgaaaac-3'

(The NdeI restriction site is italicised)

\section{Acknowledgements}

This work was supported by grants of the European Union (Eurofung II and Eurofungbase) and the Junta de Castilla and León (Project LEI3/04). C. García-Estrada is supported by the Torres Quevedo Program (PTQ04-304II) cofinanced by the ADE Inversiones y Servicios of Castilla y León (04B/07/LE/0003). I. Vaca received a fellowship of the Diputación de León. The expert help of Carlos Barreiro and Patricia Martín (Instituto de Biotecnología, INBIOTEC) with the mass spectrometry and DNA sequencing analyses, respectively, is acknowledged. Authors wish to thank B. Martín, J.
Merino, A. Casenave and B. Aguado (Instituto de Biotecnología, INBIOTEC) for their excellent technical assistance.

\section{References}

I. Martín JF, Liras P: Organization and expression of genes involved in the biosynthesis of antibiotics and other secondary metabolites. Annu Rev Microbiol 1989, 43: 173-206.

2. Álvarez E, Cantoral JM, Barredo JL, Díez B, Martín JF: Purification to homogeneity and characterization of the acyl-CoA: 6APA acyltransferase of Penicillium chrysogenum. Antimicrob Agents Chemother 1987, 31:1675-1682.

3. Martín JF, Ingolia TD, Queener SW: Molecular genetics of penicillin and cephalosporin antibiotic biosynthesis. In Molecular Industrial Mycology Edited by: Leong SA, Berka R. New York: Marcel Dekker; 1990: 149-195.

4. Lamas-Maceiras M, Vaca I, Rodríguez E, Casqueiro J, Martín JF: Amplification and disruption of the phenylacetyl-CoA ligase gene of Penicillium chrysogenum encoding an aryl-capping enzyme that supplies phenylacetic acid to the isopenicillin $\mathbf{N}$ acyltransferase. Biochem J 2006, 395: 147-I55.

5. Wang FQ, Liu J, Dai M, Ren ZH, Su CY, He JG: Molecular cloning and functional identification of a novel phenylacetyl-CoA ligase gene from Penicillium chrysogenum. Biochem Biophys Res Commun 2007, 360:453-458.

6. Fierro F, Barredo JL, Díez B, Gutiérrez S, Fernández FJ, Martín JF: The penicillin gene cluster is amplified in tandem repeats linked by conserved hexanucleotide sequences. Proc Natl Acad Sci USA 1995, 92:6200-6204.

7. Fierro F, García-Estrada C, Castillo NI, Rodríguez R, Velasco-Conde $T$, Martín JF: Transcriptional and bioinformatic analysis of the $56.8 \mathrm{~kb}$ DNA region amplified in tandem repeats containing the penicillin gene cluster in Penicillium chrysogenum. Fung Genet Biol 2006, 43:618-629.

8. van den Berg MA, Westerlaken I, Leeflang C, Kerkman R, Bovenberg RA: Functional characterization of the penicillin biosynthetic gene cluster of Penicillium chrysogenum Wisconsin54-I 255. Fung Genet Biol 2007, 44:830-844.

9. Cantoral JM, Gutiérrez S, Fierro F, Gil-Espinosa S, van Liempt H, Martín JF: Biochemical characterization and molecular genetics of nine mutants of Penicillium chrysogenum impaired in penicillin biosynthesis. J Biol Chem 1993, 5:737-744.

10. Fierro F, Montenegro E, Gutiérrez S, Martín JF: Mutants blocked in penicillin biosynthesis show a deletion of the entire penicillin gene cluster at a specific site within a conserved hexanucleotide sequence. Appl Microbiol Biotechnol 1996, 44:597-604.

11. García-Estrada C, Vaca I, Lamas-Maceiras M, Martín JF: In vivo transport of the intermediates of the penicillin biosynthetic pathway in tailored strains of Penicillium chrysogenum. Appl Microbiol Biotechnol 2007, 76:169-182.

12. Liras P, Martín JF: Gene clusters for beta-lactam antibiotics and control of their expression: why have clusters evolved, and from where did they originate? Int Microbiol 2006, 9:9-19.

13. Landan G, Cohen G, Aharonowitz Y, Shuali Y, Graur D, Shiffman D: Evolution of isopenicillin $\mathbf{N}$ synthase genes may have involved horizontal gene transfer. Mol Biol Evol 1990, 7:399-406.

14. Aharonowitz Y, Cohen G, Martín JF: Penicillin and cephalosporin biosynthetic genes: structure, regulation, and evolution. Annu Rev Microbiol 1992, 46:46I-495.

15. Peñalva MA, Moya A, Dopazo J, Ramón D: Sequences of isopenicillin $\mathbf{N}$ synthetase genes suggest horizontal gene transfer from prokaryotes to eukaryotes. Proc Biol Sci 1990, 241:164-169.

16. Barredo JL, van Solingen P, Díez B, Álvarez E, Cantoral JM, Kattevilder A, Smaal EB, Groenen MAM, Veenstra AE, Martín JF: Cloning and characterization of the acyl-coenzyme A: 6-aminopenicillanic-acid-acyltransferase gene of Penicillium chrysogenum. Gene 1989, 83:291-300

17. Veenstra AE, van Solingen $P$, Huininga-Muurling $H$, Koekman BP, Groenen MAM, Smaal EB, Kattevilder A, Alvarez E, Barredo JL, Martín JF: Cloning of penicillin biosynthesic genes. In Genetics and Molecular Biology of Industrial Microorganisms Edited by: Hershberger CL, Queener SW, Hegeman G. Washington: American Society for Microbiology; 1989:262-269.

18. Whiteman PA, Abraham EP, Baldwin JE, Fleming MD, Schofield CJ, Sutherland JD, Willis AC: Acyl coenzyme A: 6-aminopenicillanic 
acid acyltransferase from Penicillium chrysogenum and Aspergillus nidulans. FEBS Lett 1990, 262:342-344.

19. Tobin MB, Fleming MD, Skatrud PL, Miller JR: Molecular characterization of the acyl-coenzyme $A$ : isopenicillin $\mathbf{N}$ acyltransferase gene (penDE) from Penicillium chrysogenum and Aspergillus nidulans and activity of recombinant enzyme in $E$. coli. J Bacteriol 1990, 172:5908-59|4.

20. Tobin MB, Baldwin JE, Cole SCJ, Miller JR, Skatrud PL, Sutherland JD: The requirement for subunit interaction in the production of Penicillium chrysogenum acyl-coenzyme $\mathbf{A}$ : isopenicillin $\mathbf{N}$ acyltransferase in Escherichia coli. Gene 1993, 132:199-206.

21. Álvarez E, Meesschaert B, Montenegro E, Gutiérrez S, Díez B, Barredo JL, Martín JF: The isopenicillin $\mathbf{N}$ acyltransferase of Penicillium chrysogenum has isopenicillin $\mathbf{N}$ amidohydrolase, $\mathbf{6}$ aminopenicillanic acid acyltransferase and penicillin amidase activities, all of which are encoded by the single penDE gene. Eur J Biochem 1993, 21 5:323-332.

22. Queener $S$, Neuss $N$ : The biosynthesis of $\beta$-lactam antibiotics. In The Chemistry and Biology of $\beta$-Lactam Antibiotics Volume 3. Edited by: Morin RB, Gorman M. New York: Academic; 1982:I-8I0.

23. Brannigan JA, Dodson G, Duggleby HJ, Moody PCE, Smith JL, Tomchick DR, Murzin AG: A protein catalytic framework with an $\mathbf{N}$ terminal nucleophile is capable of self-activation. Nature 1995 , 378:416-419.

24. Müller WH, Krift TP van der, Krouwer AJ, Wosten HA, Voort LH van der, Smaal EB, Verkleij AJ: Localization of the pathway of the penicillin biosynthesis in Penicillium chrysogenum. EMBO J 1991, 10:489-495.

25. Müller WH, Bovenberg RA, Groothuis MH, Kattevilder F, Smaal EB, Voort LH Van der, Verkleij AJ: Involvement of microbodies in penicillin biosynthesis. Biochim Biophys Acta 1992, I I 16:2 I0-2 I3.

26. García-Estrada C, Vaca I, Fierro F, Sjollema K, Veenhuis M, Martín JF: The unprocessed preprotein form IATCI03S of the isopenicillin $\mathbf{N}$ acyltransferase is transported inside peroxisomes and regulates its self-processing. Fung Genet Biol 2008, 45: $1043-1052$.

27. van den Berg MA, Albang R, Albermann $K$, Badger JH, Daran JM, Driessen AJM, García-Estrada C, Federova ND, Harris DM, Heijne WHM, Joardar V, Kiel JAKW, Kovalchuk A, Martín JF, Nierman WC Nijland JG, Pronk JT, Roubos JA, Klei I van der, van Peij NNME, Veenhuis M, Von Dohren H, Wagner C, Wortman J, Bovenberg RAL: Genome sequencing and analysis of the filamentous fungus Penicillium chrysogenum. Nat Biotechnol 2008, 26: I I6I-I I 68.

28. Kleijn RJ, Liu F, van Winden WA, van Gulik WM, Ras C, Heijnen JJ: Cytosolic NADPH metabolism in penicilling producing and non-producing chemostat cultures of Penicillium chrysogenum. Metab Eng 2007, 9: I I 2-123.

29. Ninomiya Y, Suzuki K, Ishii C, Inoue H: Highly efficient gene replacements in Neurospora strains deficient for nonhomologous end-joining. Proc Natl Acad Sci USA 2004, I 0 I: I $2248-$ I 2253

30. Meyer V, Arentshorst M, El-Ghezal A, Drews AC, Kooistra R, Honde $C A$ van den, Ram AF: Highly efficient gene targeting in the Aspergillus niger kusA mutant. I Biotechnol 2007, I 28:770-775.

3I. Fernández FJ, Cardoza RE, Montenegro E, Velasco J, Gutiérrez S, Martín JF: The isopenicillin $\mathbf{N}$ acyltransferases of Aspergillus nidulans and Penicillium chrysogenum differ in their ability to maintain the 40-kDa alphabeta heterodimer in an undissociated form. Eur J Biochem 2003, 270: $1958-1968$.

32. Martín JF, Gutiérrez S, Fernández FJ, Velasco J, Fierro F, Marcos AT, Kosalkova K: Expression of genes and processing of enzymes for the biosynthesis of penicillins and cephalosporins. Antonie van Leeuwenhoek 1994, 65:227-243.

33. García-Estrada C, Ullán RV, Velasco-Conde T, Godio RP, Teijeira F, Vaca I, Feltrer R, Kosalková K, Mauriz E, Martín JF: Post-translational enzyme modification by the phosphopantetheinyl transferase is required for lysine and penicillin biosynthesis but not for roquefortine or fatty acid formation in Penicillium chrysogenum. Biochem J 2008, 415:317-324.

34. Keller NP, Hohn TM: Metabolic Pathway Gene Clusters in Filamentous Fungi. Fung Genet Biol 1997, 21:17-29.

35. Spröte P, Hynes MJ, Hortschansky P, Shelesty E, Scharf DH, Wolke SM, Brakhage AA: Identification of the novel penicillin biosynthesis gene aat $B$ of Aspergillus nidulans and its putative evolutionary relationship to this fungal secondary metabolism gene cluster. Mol Microbiol 2008, 70:445-46I.
36. Klein AT, van den Berg M, Bottger G, Tabak HF, Distel B: Saccharomyces cerevisiae acyl-CoA oxidase follows a novel, non-PTSI, import pathway into peroxisomes that is dependent on Pex5p. J Biol Chem 2002, 277:250I I-250I9.

37. Seemüller E, Lupas A, Baumeister W: Autocatalytic processing of the 20 S proteasome. Nature 1996, 382:468-470.

38. Tobin MB, Cole SC, Kovacevic S, Miller JR, Baldwin JE, Sutherland JD Acyl-coenzyme A: isopenicillin $\mathbf{N}$ acyltransferase from Penicillium chrysogenum: effect of amino acid substitutions at Ser227, Ser230 and Ser309 on proenzyme cleavage and activity. FEMS Microbiol Lett 1994, I 2 I:39-46.

39. Aplin RT, Baldwin JE, Roach PL, Robinson CV, Schofield CJ: Investigations into the post-translational modification and mechanism of isopenicillin N:acyl-CoA acyltransferase using electrospray mass spectrometry. Biochem J 1993, 294:357-363.

40. Laich F, Fierro F, Cardoza RE, Martín JF: Organization of the gene cluster for biosynthesis of penicillin in Penicillium nalgiovense and antibiotic production in cured dry sausages. Appl Environ Microbiol 1999, 65: 1236-1240.

4I. Laich F, Fierro F, Martín JF: Production of penicillin by fungi growing on food products: Identification of a complete penicillin gene cluster in Penicillium griseofulvum and a truncated cluster in Penicillium verrucosum. Appl Environ Microbiol 2002, 68: $1211-1219$.

42. Machida M, Asai K, Sano M, Tanaka T, Kumagai T, Terai G, Kusumoto K, Arima T, Akita O, Kashiwagi Y, Abe K, Gomi K, Horiuchi H, Kitamoto K, Kobayashi T, Takeuchi M, Denning DW, Galagan JE, Nierman WC, Yu J, Archer DB, Bennett JW, Bhatnagar D, Cleveland TE, Fedorova ND, Gotoh O, Horikawa H, Hosoyama A, Ichinomiya M, Igarashi R, Iwashita K, Juvvadi PR, Kato M, Kato Y, Kin T, Kokubun A, Maeda H, Maeyama N, Maruyama J, Nagasaki H, Nakajima T, Oda K, Okada K, Paulsen I, Sakamoto K, Sawano T, Takahashi M, Takase K, Terabayashi Y, Wortman JR, Yamada O, Yamagata Y, Anazawa H, Hata $Y$, Koide $Y$, Komori T, Koyama Y, Minetoki T, Suharnan S, Tanaka A, Isono K, Kuhara S, Ogasawara N, Kikuchi H: Genome sequencing and analysis of Aspergillus oryzae. Nature 2005, 438: $|157-||6|$.

43. Raper KB, Alexander DR, Coghill RD: Penicillin. II. Natural variation and penicillin production in Penicillium notatum and allied species. I Bacteriol 1944, 48:639-659.

44. Casqueiro J, Bañuelos O, Gutiérrez S, Hijarrubia MJ, Martín JF: Intrachromosomal recombination between direct repeats in Penicillium chrysogenum: gene conversion and deletion events. Mol Gen Genet 1999, 26 1:994-1000.

45. De Laat WTAM, Preusting JCG, Koekman BP: Fermentative production of valuable compounds on an industrial scale using chemically defined media. US patent 2002. 2002/0039758

46. van den Berg MA, Bovenberg RAL, Raamsdonk LML, Sutherland JD, de Vroom E, Vollinga RCR: Cephem compound. 2007.

47. Fierro F, Kosalková K, Gutiérrez S, Martín JF: Autonomously replicating plasmids carrying the AMAI region in Penicillium chrysogenum. Curr Genet 1996, 29:482-489.

48. Cardoza RE, Moralejo FJ, Gutiérrez S, Casqueiro J, Fierro F, Martín JF: Characterization and nitrogen-source regulation at the transcriptional level of the gdhA gene of Aspergillus awamori encoding an NADP-dependent glutamate dehydrogenase. Curr Genet 1998, 34:50-59.

49. Cantoral JM, Díez B, Barredo JL, Álvarez E, Martín JF: High frequency transformation of Penicillium chrysogenum. Bio/Technology 1987, 5:494-497.

50. Díez B, Álvarez E, Cantoral JM, Barredo JL, Martín JF: Isolation and characterization of pyrG mutants of Penicillium chrysogenum by resistance to 5'-fluorotic acid. Curr Genet 1987, 12:277-282.

5I. Swinkels BW, Selten GCM, Bakhuis JG, Bovenberg RAL, Vollebregt AW: The use of homologous amds genes as selectable markers. International Patent Application 1997. 